\title{
BANDAR SUKABUMI IN THE BEGINNING OF THE 19TH CENTURY: THE ROLE OF POLITICAL AUTHORITY IN THE DEVELOPMENT OF RIVER-CITY IN KOTAWARINGIN REGION, SOUTHWESTERN KALIMANTAN
}

\section{BANDAR SUKABUMI PADA AWAL ABAD KE-19 MASEHI: PERAN OTORITAS POLITIK DALAM PENGEMBANGAN KOTA SUNGAI DI KAWASAN KOTAWARINGIN, KALIMANTAN BARAT DAYA}

\author{
Moh Ali Fadillah \\ Department of History Education, Faculty of Education and Teacher Training Program, University of Sultan Ageng Tirtayasa, \\ Serang-Banten, Indonesia; email: ali.fadilah@untirta.ac.id
}

Diterima 2 Juli 2020

Direvisi 19 September 2020

Disetujui 8 Oktober 2020

\begin{abstract}
Kotawaringin is the name of a small kingdom founded in the first half of the $17^{\text {th }}$ century, centered in Kotawaringin Lama on the upper reaches of Sungai Lamandau, in southwestern Kalimantan. In the early $19^{\text {th }}$ century the royal capital was moved to Pangkalan Bun. The shift of the capital city is an important factor in the history of human geography as a cause of changes in demography and urbanization. This research aimed to find clarity about the agglomeration of river cities in terms of symbolic and pragmatic aspects. Such aspects include the origin, existence, reasons for shifting capital and the type of culture that underlies the function of Kotawaringin as a center of government and trade that grew during the early colonial period. The research used methods which were carried out by observing sites indicated as capitals and ports, combining it with studies of historical sources, as well as collecting physical evidence, including a number of symbolic objects associated with royal legitimacy. Results of contextual analysis provide a set of knowledge about the growth of river city as the implementation of the spatial planning policy of the government and the support of urban communities rooted in Malay culture. The Kingdom of Kotawaringin reached a peak of progress during the reign of Prince Ratu Imanuddin, after the capital was moved to Pangkalan Bun from Kotawaringin Lama. The location of the new capital is on the lower reaches of the Sungai Lamandau, precisely on the banks of the Sungai Arut, which was formerly called Bandar Sukabumi.
\end{abstract}

Keywords: Kotawaringin, Human geography, Pangkalan Bun, River city, Malay culture, Political economy

\begin{abstract}
Abstrak. Kotawaringin adalah nama sebuah kerajaan kecil yang didirikan pada paruh pertama abad ke-17 Masehi, berpusat di Kotawaringin Lama di kawasan hulu Sungai Lamandau, di barat daya Kalimantan. Pada awal abad ke-19 Masehi, ibukota kerajaan dipindahkan ke Pangkalan Bun. Pergeseran ibukota merupakan faktor penting dalam sejarah geografi manusia sebagai penyebab perubahan demografi dan urbanisasi. Penelitian ini bertujuan untuk mengetahui kejelasan tentang aglomerasi kota sungai ditinjau dari aspek simbolik dan pragmatis. Aspek-aspek tersebut mencakup asal usul, keberadaan, alasan perpindahan ibukota dan jenis budaya yang mendasari fungsi Kotawaringin sebagai pusat pemerintahan dan perdagangan yang tumbuh pada masa kolonial awal. Penelitian ini menggunakan metode yang dilakukan dengan mengamati situs-situs yang diindikasikan sebagai ibukota dan pelabuhan, memadukannya dengan studi sumber-sumber sejarah, serta mengumpulkan bukti-bukti fisik, termasuk sejumlah benda simbolis yang terkait dengan legitimasi kerajaan. Hasil analisis kontekstual memberikan seperangkat pengetahuan tentang pertumbuhan kota sungai sebagai implementasi kebijakan perencanaan tata ruang pemerintah, dan dukungan masyarakat kota yang berakar pada budaya Melayu. Kerajaan Kotawaringin mencapai puncak kemajuan pada masa pemerintahan Pangeran Ratu Imanuddin, setelah ibu kota dipindahkan ke Pangkalan Bun dari Kotawaringin Lama. Lokasi ibu kota baru berada di bagian hilir Sungai Lamandau, tepatnya di tepi Sungai Arut yang dahulu dinamai Bandar Sukabumi.
\end{abstract}

Kata kunci: Kotawaringin, geografi manusia, Pangkalan Bun, Kota sungai, Budaya Melayu, ekonomi politik

\section{INTRODUCTION}

The existence of a royal capital city in the Malay world in the period of Islamic history is always interesting to study, both from the physical and socio-economic dimensions. The prominent character of a royal capital city in an urban landscape can make a difference from rural settlements, especially in Kalimantan, Indonesian Borneo. Archaeological research supported by ethnohistoric sources relating to the subject revealed various cultural phenomena in the spaces 
occupied. In the case of Kotawaringin in the southwestern region of Kalimantan, this brief growing period of river city can be explored through traces of its past which began with the decisive journey of a prince of the Banjar dynasty to 'open a new country' known as the Buka Negeri tradition (Logan 1848; the case of Kotawaringin, Figure 1).

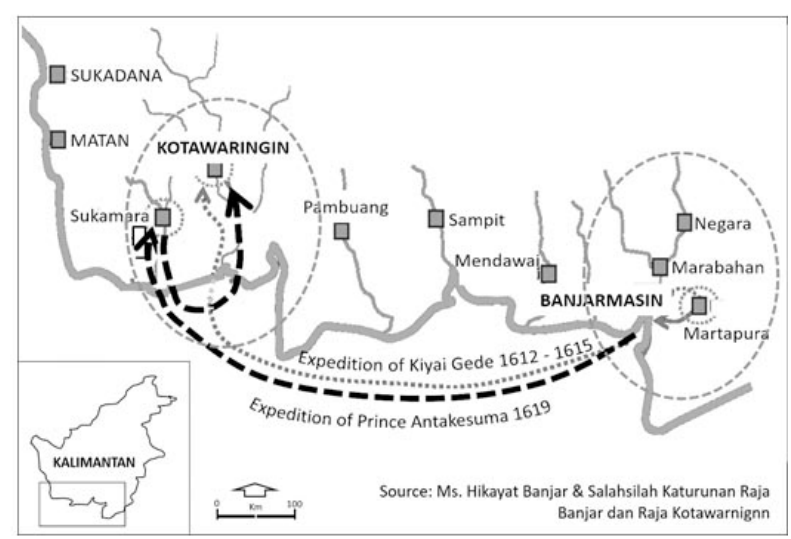

Source: Ras 1990

Figure 1 The Territorial Expansion of the Banjar Dynasty to Kotawaringin

In a fairly old tradition, the determination of urban and rural locations in Kalimantan is always river-oriented. Since the $14^{\text {th }}$ century, as mentioned in the Nagarakertagama text, almost all Majapahit tributaries in Nusa Tanjung Negara (Kalimantan today) have been located in coastal areas or on the banks of rivers that are easily reached. Kutai and Pasir on the east coast, Baritu, Sampit, Kutawaringin on the south coast, while Tanjungpuri, Lawe, Landak, and Sambas are located on the west coast (Pigeaud 1963; also see Fadillah 1998). Some evidence of Majapahit influence was found at the open site of Candi Laras, in the southeastern region of Kalimantan, such as the brick structure, Hindu relics, inscription in Sanskrit and its associated findings which are thought to originate from the golden age of Majapahit (Kusmartono and Suhadi 1997; Sulistyanto 2000). While at the Negeri Baru site, the old Tanjungpura area, in Ketapang, in the province of West Kalimantan, researchers have discovered also ancient Islamic tomb complexes with ancient Javanese inscriptions and also brick structures from the same era as stated in the news of findings in 1993 and that gave a reason for archaeological excavation at the site (Atmojo 2013; see also Amerta Berkala Arkeologi, 14, 1993/1994;
Hindarto 2017). Between the $16^{\text {th }}$ and $17^{\text {th }}$ centuries, the coastal cities of the 14th century continued to develop under the Islamic regime (Manguin 2000). The new cities include Pontianak (Lombard 1984), followed by Mempawah, Sukadana, Sambas (Kratz 1980) as well as Martapura and Banjarmasin (Ras 1990) that grew as the center of the Malay sultanate cities.

Evidence found in the Kotawaringin river catchment, in the Lamandau and Arut branches, still leaves some physical and cultural traces which are thought to originate in the $17^{\text {th }}$ century. The problem is that there is a very limited source of information about the history of Kotawaringin. It is acknowledged that the principality or 'princedom' of Kotawaringin was also the heir of the Banjar dynasty (Dijk 1962). However, the attention of scholars was more directed at the Banjar sultanate, the royal 'mother' who initiated the birth of Kotawaringin four centuries ago.

The tendency for a subjective choice can be understood because since the early $17^{\text {th }}$ century Banjarmasin has played an essential role in the political and economic domain. Many foreign traders such as the Dutch, British and Chinese as well as traders from other regions in the archipelago have visited and traded in Banjarmasin (Gais 1922). In the second half of the $19^{\text {th }}$ century, due to economic motives, the sultanate faced various pressures from the colonial regime until finally lost its sovereignty (Rees 18651867). The dramatic contestation as the 'Banjar War' did not occur in the history of Kotawaringin.

This Kotawaringin region, therefore, was spared from total destruction whose historical and archaeological remains, though mostly made of wood, still give us some objective testimony about their existence. Such a reason may have caused Kotawaringin less attractive to historians. Kotawaringin is only known as a peripheral country whose historical discourse is still shrouded in legend. However, such status was not substantial. The most important issue is that until the 1990s there were no specific studies from the disciplines of history, archaeology, and other social sciences in the area (Fadillah et al. 1990).

The present research focuses on the urban spatial planning and ports related to Kotawaringin to obtain specific ideas that underlie the formation of a Malay estuary civilization in the lowlands of Kalimantan. The main problem starts from the 
fundamental question, what is the role of the Kotawaringin political authority in spatial planning which has implications for the development of river-city culture? The answer to that question is expected to be able to explain whether the design of cities in Kotawaringin shows a certain uniqueness and whether it has the same prototype as other estuary cities in the Indonesian archipelago. Based on a social perspective, it is also necessary to look at the relationship between urban planning and local authority policies in strengthening the economic functions of the city.

\section{METHODS}

The research was conducted using two complementary methods, i.e. archaeology and history. The archaeological method employed field analysis during surveys at various locations along Sungai (river) Lamandau, Kumai, and Jelai. It also required metric analysis and a description of structures and materials, both from the excavation and surface findings. The historical method mainly involved analysis of available and unpublished documents concerning Kotawaringin which were directly collected in the field. Such documents include the Malay-Banjarese chronicles and archives of the principality, as well as the Dutch colonial archives. Oral traditions were also collected from both the Malay and the Dayak communities, which constitute additional sources.

The interpretation was drawn from data analyses using synthetic methods by integrating archaeological evidence, historical sources and oral traditions. Further, it was supported by the results of technical works, particularly site maps and construction drawings, on the restoration of ancient buildings in Kotawaringin Lama and Pangkalan Bun conducted by the Government of Indonesia (Ditlinbinjarah 1980; Ditlinbinjarah 1984).

\section{RESULT AND DISCUSSION}

\section{Hypothetical Reconstructions of Kotawaringin Lama}

Archaeological and historical surveys at the urban sites of Kotawaringin Lama and Pangkalan Bun conducted in 1990, 1994-1995, and 2016. The researches were aimed to obtain adequate information about important places in the transition period, from an independent country to a colonial regime. Some of the remaining buildings show a certain characteristic and provide a set of aspects of Islamic civilization from the former principality of Kotawaringin. Results of field observations indicated the first capital city was located in a place now called Kotawaringin Lama, an area of 2.8 ha in width, which for nearly two centuries did not show significant changes (Fadillah 1996). In the initial stages, the capital may be inhabited by people from the Banjar ethnic group who are mostly migrants from the south coast of Borneo. Based on the oral tradition this place was more impressive as the agglomeration of the residences of the Banjar aristocracy and some Dayak ethnic groups who had embraced Islam and dozens of Chinese descent from western Kalimantan; had inhabited the upstream mining location called Parit Cina (Chinese Trench).

In contrast, the second capital in Pangkalan Bun that occupies an area of 4.2 ha in width, which is twice the size of Kotawaringin Lama. Since the beginning of the 19th century, Pangkalan Bun has been a heterogeneous settlement characterized by a large population. In his report of 1853, Von Gaffron announced that the population consisted of 13,360 people, and in 1913 the number increased to 20,898 . Generally, the inhabitants of Pangkalan Bun consists three major groups, i.e. the Dayaks, who are considered as the indigenous people; the Malays, although most of them came from Banjarmasin, they represented a large part of the waterside community; and foreigners, including Javanese, Buginese, Arab, and Chinese (Pijnappel Gzn 1860; Encyclopaedie van Nederlandsch-Indie, 1896, II: 440 1940)

Referring to the oral tradition and reinforced by material traces in the form of buildings related to the existence of the country, it is estimated that since the second half of the $17^{\text {th }}$ century, the first royal capital, Kotawaringin, was designed as a type of 'river city'. The characteristics of such settlement, of course, are not unique to Kalimantan. A royal city is marked by an alun-alun (public square) placed between a palace and a river, where the palace faces a river. A river was the only communication access that opened up the isolation of a country for a maritime trade route on the southern coast of Kalimantan (Fadillah 1996). As a consequence of such river settlement pattern, the harbor would have been theoretically located 
on the banks of the river overlooking the royal palace (site description, Figure 2).

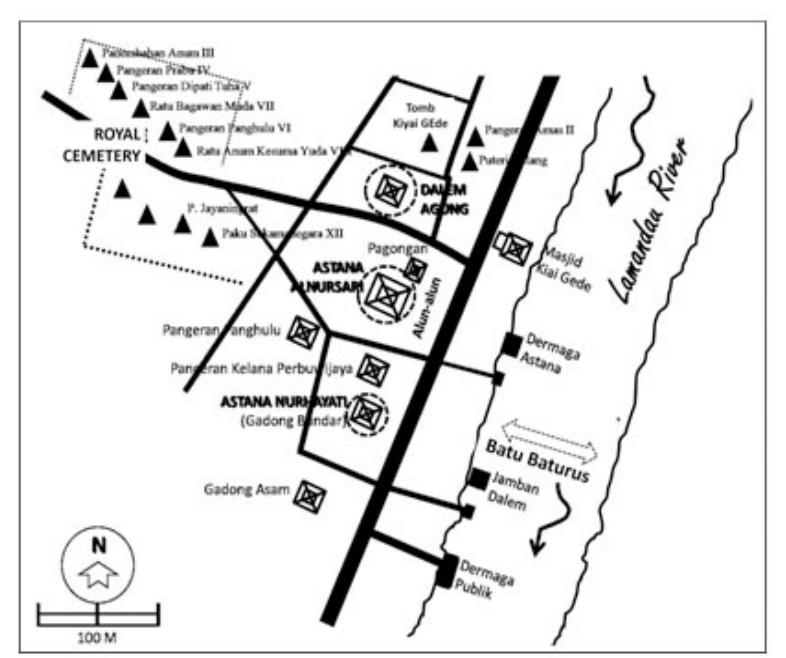

Source: Fadillah et.al. 1990

Figure 2 The Situation of Kotawaringin Lama based on Archaeological Remains

Site surveys did not find remains of the first palace which was built during the era of the 1 st prince, Adipati Antakesuma, who was one of the sons of Mustain-Billah, the $4^{\text {th }}$ Sultan of Banjar (Ras 1990). Brief information, called Dalem Agung (great palace), that was collected from the locals indicated the once existed wooden structures vanished leaving no trace after passing through two centuries, except for an empty spot upstream from the present settlement. Although overgrown with a large tree surrounded by a fence, the place still receives respect from the local inhabitants who consider it a very sacred place. One of the strongest clues, around the old palace emplacement was indicated by the old tomb of a figure believed to be contemporary to that of Prince Antakesuma (Mallinckrodt 1925). This association gives a reason to consider that the palace which marked the formation of MalayIslamic civilization began in the first half of the $17^{\text {th }}$ century in the upstream reaches of Sungai Lamandau.

At that time, an old mosque called Kiyai Gede, which was arguably a landmark in the capital of the Islamic country of Kotawaringin, was located right on the riverbank. This ancient mosque was probably built for the first time by Kiyai Gede or Dipati Ngganding, in the early $17^{\text {th }}$ century, with his followers from Martapura (or Banjarmasin) soon after opening a residence in that place (Figure 3). The Kiyai Gede mosque in
Kotawaringin Lama is recognised as the first Islamic holy building established in the interior of the southwestern region of Kalimantan. Built on sturdy pillars and shaped by wooden construction of local wood, the bulin or ulin (Eusideroxylon zwageri), this mosque still shows the type of classical Javanese architecture. The characteristics of such mosque is mainly marked by four saka guru or main pillars which are decorated with floral carvings, and support the pyramid-shaped roof (Ditlinbinjarah 1984). Compared to old habits in Java where the mosque is always erected to the west of a square, the Kiyai Gede mosque is of course located near Sungai Lamandau (Sudibyo 1984). Thus, there is no doubt, the river remains an important part not only for transportation facilities but also for the Muslim community in worshipping activities in Kotawaringin Lama. The mosque which was built near the river was apparently meant to make it easier for people to take ablution water before prayer (Figure 4). Regarding the origin of the ancient mosque in Kotawaringin Lama, Kunto Sofianto and Masmedia Pinem suggest that the mosque was built in 1052 Hijrat or 1632 CE by Kiyai Gede, after receiving an Islamic education from Sunan Giri in Gresik. Kiyai Gede was considered to be a religious scholar from the Sultanate of Demak. Accompanied by some of his followers, he arrived in Kalimantan in 1591, when Banjarmasin was under the authority of MustainBillah (Sofianto and Pinem 2015).

The exact date proposed for the early phase of the history of Kotawaringin cannot be ascertained because the source of information is based only on local oral traditions. However, based on oral traditions and limited archaeological data, it is not yet the time to present an explanation on the first capital city in full description. But at least, the position of the palace can be imagined as the center of orientation in the city. Unfortunately, there is no monumental evidence left from the first palace, but its existence has been mentioned in one of the Malay manuscripts written in the $19^{\text {th }}$ century in that place (Fadillah 1996). It may be interesting to mention here that the existence of an old grave complex can refer to the location of the former palace. 


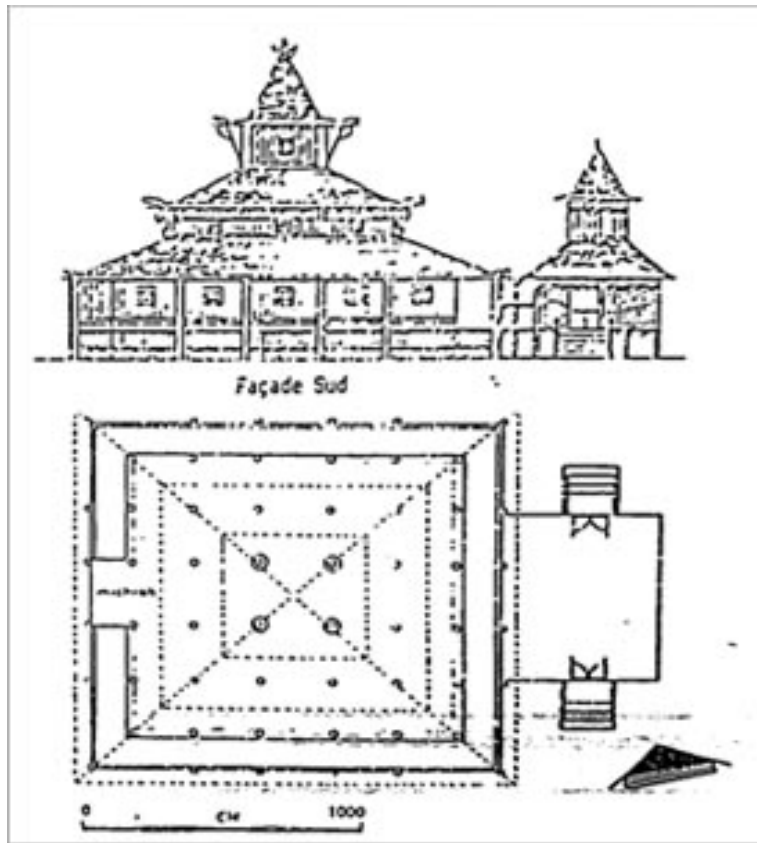

Source: Ditlinbinjarah 1984

Figure 3 A Sketch and Plan of Kiyai Gede Mosque in Kotawaringin Lama

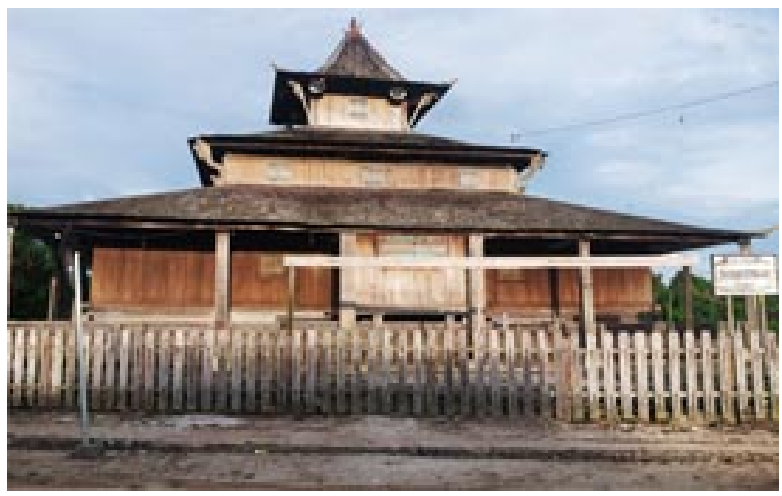

Source: Photo by author

Figure 4 The Kiyai Gede Mosque in Kotawaringin Lama (2015), has been well maintained

To the north of the palace was found tombs of the second king, Pangeran Amas, and his prime minister, Kiyai Gede, as mentioned in an unpublished manuscript (Cense 1928, note 2; Fadillah 1996: App.1 Carita Kiai Gede). Referring to the proportion of space, it is suggested that the palace and residence of the royal officials became the main structure in the capital. In the concept of city agglomeration, the hypothesis can be stated that there were no other buildings in front of the palace, except the mosque, the square and the river. Another structure from the same period was found standing in the middle of the river, named Batu Baturus, about $300 \mathrm{~m}$ south of the palace. The structure was made of andesite piles which serve as a 'stop sign' for vessels entering or passing through the city (Fadillah 1996, Part 1.
Donnees archeologiques). Such inference was made clear by a toponym that is still preserved in the collective memory of the locals in the form of a Dermaga Raja (king's pier) or Dermaga Istana (palace pier), where commercial vessels docks after passing through Sungai Lamandau from Teluk Kotawaringin.

The second period of the royal house was marked by the establishment of the Nurhayati Palace (Arabic: the light of life), which functioned during the reign of the $7^{\text {th }}$ king, Prince Ratu Bagawan Muda (1727-1767), and the 9th king, Prince Ratu Imanuddin. Based on the in situ remnants of the main wooden pillars, this palace is located about $420 \mathrm{~m}$ south of the first palace (Fadillah 1996). According to Von Gaffron, the palace was designed to follow the Javanese building model. The Javanese palace is generally a complex of buildings with the main structure constructed as a symmetrical square crowned with a pyramid-like roof. In a local tradition, it is said that the observed palace adopted an almost spherical shape, which distinguishes it from the rectangular architecture of Keraton Kuning (yellow palace; will be described after this), located in Pangkalan Bun. Perhaps because of its outward appearance which resembles an octagonal shape. The Nurhayati Palace is also called Gadong Bundar or round building (Pijnappel Gzn 1860).

Regarding the second palace, its presence at the identified location marked a shift of the royal house to the south. The image of the city thus changes following the central palace. By keeping the alun-alun square in front of the palace, the mosque also still stands in its original place. However, the king's pier must have been moved to provide direct access between the river and the new palace. While the public pier is located to the south of it. During this time, the royal tomb complex, called Kuta Tanah, was moved west, far from the city center. Such action must have been proof of population growth.

At the beginning of Prince Ratu Imanuddin's reign, he built a fort about $3 \mathrm{~km}$ south of the capital, which is located on a meandering river, called Taluk Benteng (fortification bay). The fort was actually two high grounds which each was constructed on opposing river cliffs, and where the poles were erected. A metal chain was suspended above Sungai Lamandau, connecting the poles from one cliff to the other. Under normal circumstances, the chain was lowered into the 
river, and if there was a security disturbance, the chain can be stretched and strained over the river; strong enough to stop a ship from reaching the capital.

Since 1811 , as soon as the new palace in Pangkalan Bun was completed, the old capital city of Kotawaringin naturally lost its main function. Afterwards, even though Kotawaringin functioned only as a residence for Mangkubumi and several other officials from the reigns of Prince Imanuddin and Prince Paku Sukmanegara (the $12^{\text {th }}$ king), the spatial structure of the Kotawaringin Lama, based on a hypothetical reconstruction above, still has an impressive royal city pattern. The Astana Alnursari was built around 1867 and has been preserved by presenting itself as a shadow of the royal palace with a private square and a pier to its front (Figure $5)$. On the other hand, the residences of other nobles were placed on equal footing with it, such as Pangeran Panghulu and Pangeran Kelana Perbuwijaya in the position of Perdipati Menteri (Gusti Aminullah 1994 pers.comm). The Public pier is always located to the south (downstream) of the old royal house. This particular pattern seems to have been preserved until now, with some changes marked by the establishment of new buildings on the riverbank, obstructing a direct view from the bank of Sungai Lamandau.

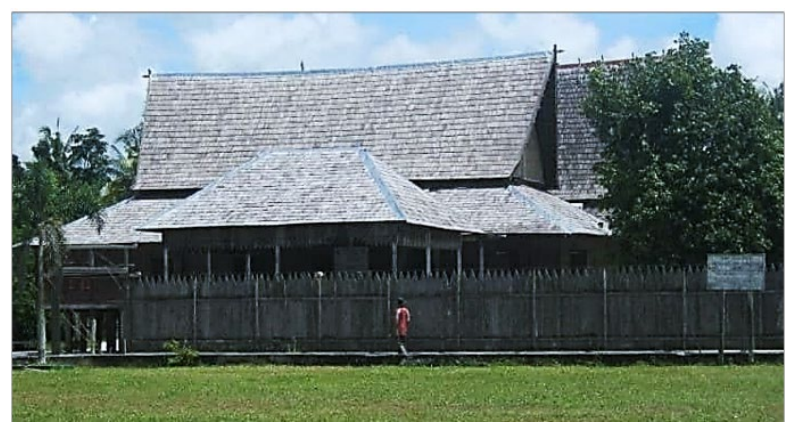

Source: Doc. Photo by Gusti Samudra 2012

Figure 5 The front view of Astana Alnursari in Kotawaringin Lama

\section{Spatial Designs of Bandar Sukabumi}

The spatial structure of the second capital city, Bandar Sukabumi, was identified. This location is now better known as Pangkalan Bun, where the heart of the city is called Kampung Raja (king cluster), with its center at the Keraton Kuning (yelllow palace). The first impression of the physical structure of the palace was that it displays the traditional design of Kalimantan. The 'legs and body' parts of such building are reminiscent of a betang or Dayak traditional longhouse (Usop et al. 1979). The main characteristic of the longhouse lies in its elongated shape which gives a horizontal impression, especially in the complex of royal palace. However, the simplicity of the usual building shape is eliminated by making the roof stand out.

The palace complex was formed of three main buildings, i.e. Pendapa (meeting room), Gadong Kuning (yellow building), and Rumah Basar (large house). The pendapa, the first building element (Javanese: pendopo) has a slightly different shape to those of buildings in Java, which are generally almost square. The pendapa has a rectangular shape that adopts from a longhouse prototype. However, its function as a meeting room shows similarities with wantilan in traditional Balinese buildings. The pyramid-shaped double roof is a unique type in Kotawaringin Regency. No roof structure alike was found in any other large buildings around southwestern Kalimantan (Figure 6).

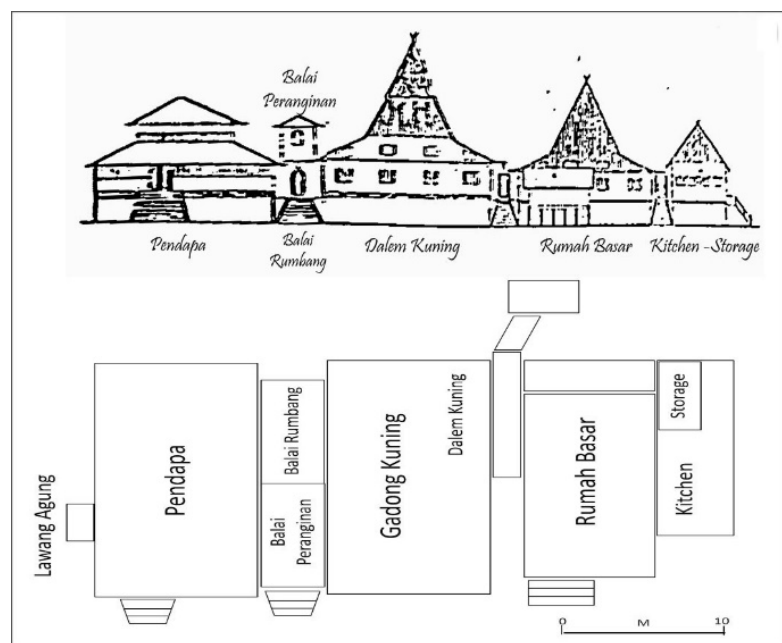

Source: Ditlinbinjarah 1980; Fadillah et.al. 1990

Figure 6 A Sketch of Keraton Kuning of Indra Kencana in Pangalan Bun built in 1809 and Caught Fire in 1986

The second building element is Gadong Kuning, established behind the pendapa, and has a saddle-like roof with high peaks similar to those of Malay traditional houses. Such structure shows a harmony between the high roof and the base of the building from the construction of a short pole. The overall physical representation gives a monumental characteristic that is directly related to its function as the main building of the palace. 
Another building is only a rectangular stage structure with also a saddle-type roof, a common type of a Malay traditional house, with a V-shaped inverted roof consisting two covers on both sides called tebar layar (spread screens) (Nasir 1985). The structure shows that the roof is a hierarchical parameter for each building in the palace complex. The Gadong Kuning roof, for example, symbolically gives the impression of a mountain peak.

Different status symbols of architectural works also appear in the division of space. In practice, Balai Rumbang is a connecting element, but physically it must be seen as a 'boundary' between a semi-public area, the Pendapa, and the Gadong Kuning, that is not accessible to the public (Figure 7). The existence of Balai Rumbang is quite essential according to the tradition of the Kotawaringin palace. On the second floor of Balai Rumbang there is a structure called the Balai Peranginan, a relaxation room or lounge, where the prince and his immediate family could rest there (Figure 8). This building element will be the last access for panakawan (servants) or ponggawa (palace officials) to escort the prince to Gadong Kuning. A gate was provided on one side of the Balai Rumbang, but was reserved for the king and his close family, while the public gate is placed in front of the pendapa called Lawang Agung (main gate). Thus, to reach Gadong Kuning is as difficult as entering a palace in a Javanese palace complex. Further, Gadong Kuning seems to be presented as dalem; the holiest structure in the palace complex. That is why it is also called Dalem Kuning (yellow core) (Ditlinbinjarah 1980).

Related to its symbolic function, Bandar Sukabumi is located on a hilltop called Indra Kencana, a reminiscent of Indo-Javanese mythology where Mount Mahameru is seen as the abode of Lord Indra whose palace is located on the top of a mountain. To support this symbolic function, a water park called Tamansari was placed in the front yard of the palace. During the first survey in 1991, the trail was not seen because it was used as a town square, which is a public space for the citizens of the modern city of Pangkalan Bun. Another Tamansari was located to the north of the palace where a number of large trees still stand and give an atmosphere of a royal garden. There are no more traces of the Tamansari but the local inhabitants still remember it and call that place Kebun Raja, which is an inseparable part of the Tamansari in the Keraton Kuning complex (Fadillah 1996).

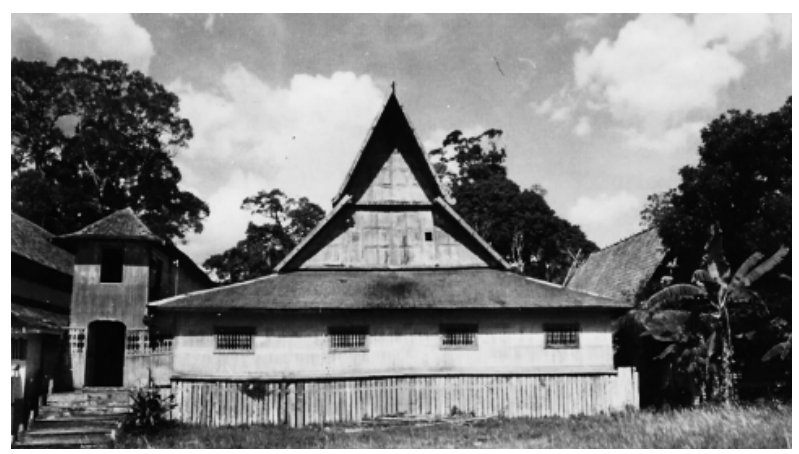

Source: Ditlinbinjarah 1984

Figure 7 Keraton Kuning of Pangkalan Bun in the 1980s

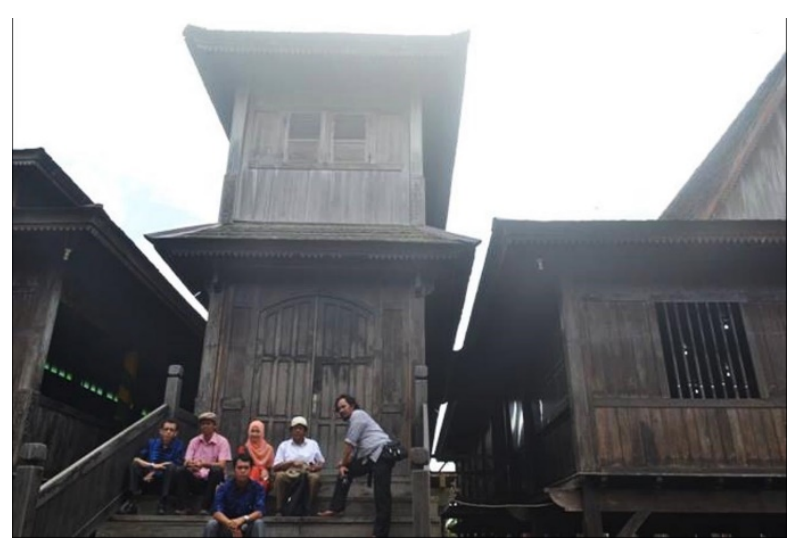

Source: Doc. Author 2015

Figure 8 The replica of Keraton Kuning built in the 2000s as a Tourist Destination in Pangkalan Bun. The Balai Rumbang part is Flanked by the Pendapa and Gadong Kuning

With such perspective, the Keraton Kuning on Bukit (hill) Indra Kencana gives the impression of a prototype palace that was influenced by other cultures. However, elements of local culture especially house on stilts and wooden materials, allow the creation of a combined design that gives a 'different feel' to the riverfront landscape. Built in the early $19^{\text {th }}$ century, the new palace of Kotawaringin, as such, has a fundamental function as a symbolic center of the city. The use of traditional Malay-Banjar or Javanese elements adds a grandeur nature by showing the uniqueness of the Kotawaringin palace and did not really adopt the Banjar or Javanese architectural style.

As was found in Kotawaringin Lama, the king's wharf in Bandar Sukabumi is on the bank of Sungai Arut, about $300 \mathrm{~m}$ to the west of the palace. The road connecting the pier and the royal 
palace during the study was still visible in the north of the alun-alun, which is now cut off by an asphalt road along the riverbank. The king's wharf serves the berths of large ships or river vessels directly related to the palace. Both Malay traders and Dayak leaders who were invited on seba occasions, a visit to the Prince, to the palace usually bring agricultural products. This king's pier, in the 1980s, still left a small stilt house on the banks of Sungai Arut called the Pasanggerahan, where royal guests or Dayak's chiefs could spend the night there.

The residences of the nobles and royal officials were placed north of the square. Today, this place has been replaced by office buildings, shops, and citizen houses. The only building remaining is the residence of Mangkubumi, the Prime Minister, from the reign of the $13^{\text {th }}$ king (1914-1935 CE) and the $14^{\text {th }}$ king (1935-1948 CE), about 200 meters east to the Keraton Kuning. By adopting a construction similar to that of the palace model, the residence of Mangkubumi was much smaller. It consists of Balai Buntar (waiting room), Bangsal (meeting room), and Rumah Basar (private room with family members). To the south of the square was a large stage house intended for the residence of Controleur van Cottawaringin, which was built during the reign of the $12^{\text {th }}$ king, Prince Paku Sukma Negara (1904-1914 CE). The building was used as the official residence of the West Kotawaringin Regent between 1990 and 1994 (Figure 9 Map of Bandar Sukabumi).

As in the first capital in Kotawaringin Lama, there was a necropolis (nécropole royale) in Bandar Sukabumi. The tomb complex of the Kotawaringin dynasty was placed on the hill Indra Kencana about 300 meters south of the palace. The royal tomb complex did not appear to have been designed in a patterned layout. Special treatment was mainly directed at the construction of graves that indicated social status. Without giving a sacred impression, even some graves that were generally made of wood have been damaged by weathering. The tombs that still look preserved are the tombs of Prince Ratu Imanuddin, of the $13^{\text {th }}$ king, and their immediate family, who are protected by a permanent dome-walled building. The shape, decoration, and materials of the noble grave in Pangkalan Bun are elements that indicate the social status of a buried figure. Tomb structures were generally built using high foundations, sometimes up to two or three levels, where cylindrical or octagonal grave marks (nisan or maesan) of wood or marble, were erected. Decorative motifs of plants, Arabic calligraphy, and geometric patterns adorn the foundation and tombstones (Fadillah 1996; Figure 10).

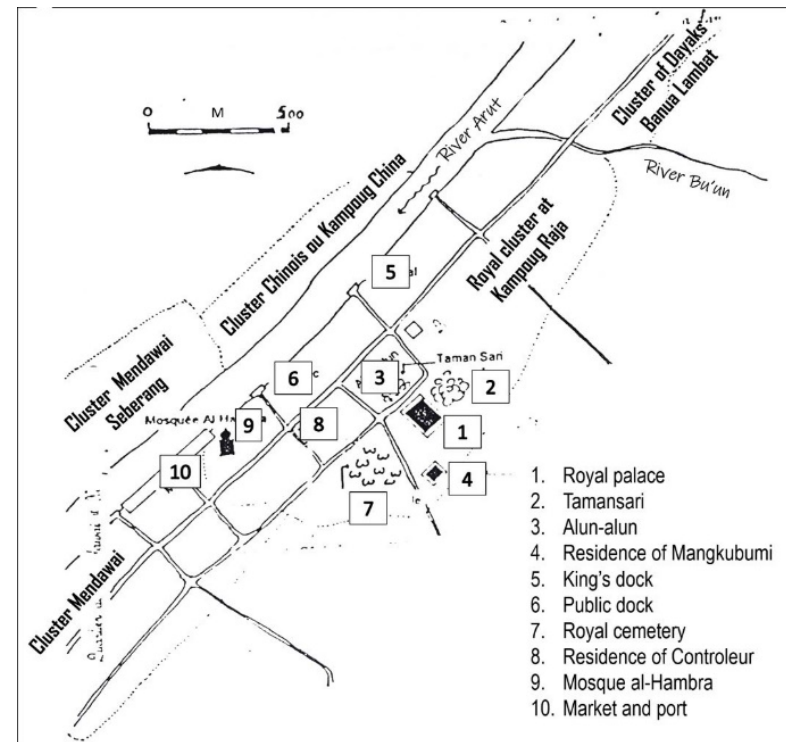

Source: Ditlinbinjarah 1980; Fadillah et.al. 1990

Figure 9 The Situation of Bandar Sukabumi or

Pangkalan Bun based on Historical Monuments and Old Toponyms

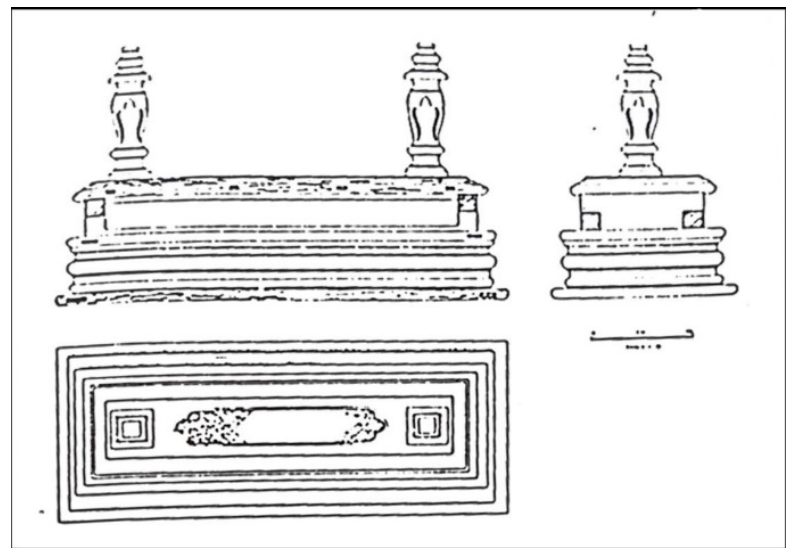

Source: Fadillah 1996 (Fig. V.1)

Figure 10 The Type of Royal Tomb in the Royal Cemetery of Kotawaringin Lama and Pangkalan Bun

Outside of the palace complex, and located precisely on the left and right riverbanks of Sungai Arut, are several clusters of housing which associate to the origin of the population. The first is called Banua Lambat, located north of the city center, bounded by Sungai Bu'un, which empties into Sungai the Arut. The village is now part of the increasingly densely populated city of Pangkalan Bun. Oral tradition provides the original version of 
the origin of the name Pangkalan Bu'un. In the early $19^{\text {th }}$ century, the small village of Banua Lambat was integrated into the city of Bandar Sukabumi. However, the name that remains popular today is Pangkalan Bun, which refers to the pier on Sungai Bu'un. Bu'un' was the name of the Dayak Arut community who first settled around the place.

The second cluster was Kampung Mendawai which is located south of Kampung Raja. Until 1994 the administrative system in Pangkalan Bun city continued using the term desa, before it was updated into a kelurahan system, as a sign of an already complex settlement. The village Mendawai was probably built before the founding of Bandar Sukabumi. In an oral tradition, it is said that it was a village inhabited by people who came from Sungai Mendawai, one of the large rivers, running parallel to Sungai Barito, not far from the Banjarmasin estuary. The Mendawai were immigrants, who under the pressure of Sultan of Banjar and with concessions from the Kotawaringin authorities, they then built settlements on the banks of Sungai Arut, gave the nuances of the diversity of the urban population in the capital city of Kotawaringin. The descendants of the Mendawai people, most of them are traders and fishermen, still maintain the traditions of their ancestors by making handicrafts, especially, tudung or tetudung made of woven pandanus that grows on the banks of Sungai Arut. The main function of tudung is to cover ready-served food. Since the $17^{\text {th }}$ century, tudung has been one of Kotawaringin's merchandises (Dagh Register 1626; keyword Toedoeng, Cottawaringen). Mendawai village was growing by occupying both sides of the banks of Sungai Arut. These villages were named Mendawai and Mendawai Seberang.

No less important in this agglomeration is the role played by Chinese people. It is mentioned in a daily conversation with Pacinan or Kampung Cina, that in 1991 both kampongs was administratively included in the Raja Seberang village. Today, the Chinese cluster is still located on the riverbank, opposite the King's cluster. This village was established almost at the same time as the founding of the royal capital city. Most of the population are descendants of the Hakka people (South China), who are mostly migrants from Pontianak and Sambas (West Kalimantan Province). They are generally former gold miners who have been employed by local authorities and have subsequently changed professions as traders.

\section{The Capital City: An Exemplary Center}

After analyzing the determinants of large settlements in all Kotawaringin historical sites, it can be inferred that Kotawaringin Lama and Bandar Sukabumi show characteristics of riverine cities that have developed from old traditions in the lowlands of Kalimantan. Although it was built in 1809-1811 CE, specifically regarding the urban site of Bandar Sukabumi, the starting point of the colonial order, the existence of the Keraton Kuning there became a symbol of feudal power under the authority of Pangeran Ratu, the local name for the crowned king. However, from the beginning of the $20^{\text {th }}$ century until now, people are more accustomed to referring to the royal city as Pangkalan Bun, which historically was an old toponym of the official name of Bandar Sukabumi (Figure 9).

The importance of capital can be characterized by its function as a political and economic center. However, conceptually Bandar Sukabumi has not experienced major changes where the river still remains an orientation point and gives the characteristic of coastal traditional life. The physical appearance of the palace still faces the river as it was found in Kotawaringin Lama. This aquatic orientation also influences the city layout where the main buildings such as mosques, public squares, and the enclaves of the settlement are located along the riverbank. While the palace, the residence of the nobles and the royal tomb complex is placed on a hill that stretches from east to southwest. Looking at the capital's spatial plan in detail, the position of the palace shows the focal point of the exclusive cluster, while the other villages are scattered around the center which is separated based on ethnic differences. As described earlier, the Mendawai settlement unit is inhabited by immigrants from the Mendawai region located southwest of the King's cluster. Banua Lambat is the Dayak-Arut village located northeast, while the Chinese cluster is located on the banks of Sungai Arut, across the King's cluster.

Considering its economic function, a capital is identical to a commercial center, but the position of the palace still shows the classic nature of a city-state. Henri Chambert-Loir's argues that the 
city of Bima in Pulau (island) Sumbawa, from the same period, reinforces the analysis that the characteristic of a city from the center of a country is not always determined by the physical size and number of buildings. Therefore, he proposed that the character of such agglomeration cannot be determined by physical criteria, such as the population, importance of buildings, and the existence of fortifications, but is also indicated by the origin, division of labor, and profession of the population (Chambert-Loir 1989). Therefore, in order to determine the characteristic of the 'royal city' in Kalimantan can be understood by the composition of the population and availability of natural resources, concentration of symbols of power, frequent contact with outsiders, and the dynamics of cultural and religious life.

Looking at the cluster of royal residences on Bukit Indra Kencana, it seems that those were constructed there intentionally to avoid the danger of flooding during the rainy season. On the other hand, Bandar Sukabumi was established in a tidal swamp area. The royal cluster includes a rather steep hilly plateau at an altitude of $15-20 \mathrm{~m}$ above sea level (masl). Such positioning gave an impression of a natural fortress that separates royal cluster from other villages, which are located in river valleys with elevations of 1-5 masl.

However, from a cosmic perspective, the Keraton Kuning is symbolically a representation of the celestial archetype of Indra's palace in Suralaya. Based on such conception, the country is seen as a 'small world' in the universe, so it must be in accordance with the 'great world' or macrocosm. According to this conception, the harmony of the two worlds will guarantee the continuation of the small world, the microcosm. To achieve such harmony, the authorities had made certain symbols placed in the palace complex (Behrend 1989).

In the case of Bandar Sukabumi, there were some indications associating with the classic IndoJavanese palace concept. In the building element called dalem, the most sacred space of a palace, the prince identifies himself as the center of buwana alit (small world), which he portrays himself to enthrone in Bukit Indra Kencana. Such depiction recalls the heavenly palace of Lord Indra, which is decorated with gold and gems at the peak of Mount Meru (Heine-Gelderen 1956; Behrend 1989). The implementation of such conception upon the palace, the building was painted in yellow; a kind of metaphor for a palace lined with gold; the symbol of grandeur and eternity. Meanwhile, physically, the towering roof of the palace shows a row of mountains. In this case, it is not a coincidence that the roof of the 'yellow building' was built higher than other buildings. It seems that there is uniformity in terms of color. The are a number of existing palaces in the center of the country painted in yellow combined with green such as the Sultanate Palace of Pontianak and Matan (old Tanjungpura) in West Kalimantan Province.

Such is why the palace is imagined to be above a mountain cluster, with a peak, locally called atap bubungan tinggi (high ridge roof), leading to an interpretation that the palace is situated on the top of an 'imaginary mountain'. Such location will be far away from the life of the port city, the market and the traffic of people and goods full of worldly interests. Looking from another perspective, such speculation can be ignored, because naturally, assembling a high roof can reduce heat in a tropical climate, especially Kalimantan which sits on the equator. Such construction will make a palace more convenient to live in. Based on the shape and style of the building as a whole, showing differences in nuances, the palace may contain a certain meaning. Therefore, it can be inferred that if a palace was constructed to accommodate the demand for 'physical functions', the architecture will show a 'tasteful mind'. It is likely that dualism will refer to certain ideological foundations.

The spatial structure of the royal city which is full of symbolic meaning seems to be a model that must be emulated by other satellite cities in the Kotawaringin region. The Kotawaringin Lama site, the first former capital city, shows a pattern similar to that of Bandar Sukabumi. In fact, the official residence of Mangkubumi has also replicated the pattern of Keraton Kuning as illustrated by the space division and building style of Astana Alnursari. However, the latter does not have a yellow building that contains the king's throne (BPCB Kaltim 2019; Figure 11). Similar structures were also found in the port cities of Kumai and Sukamara, where the city center was marked by a public square, an aristocratic residence (appointed as the head of the region), a syahbandar office, and other facilities. Usually, 
around the square, there are mosques, markets, docks and residential areas. All structures are bound at one point. The palace of the 'Little Prince', which is responsible for Pangeran Ratu at its center, that is the 'Keraton Kuning of Indra Kencana'. Due to its yellow color, the royal palace in Pangkalan Bun got its name Keraton Kuning (Yellow Palace). The color yellow is now the official color of the country. When the $10^{\text {th }}$ Festival of Indonesian palace (Festival Keraton Nusantara) took place on 9-12 October 2016 in Pangkalan Bun, the organizers of the cultural event, including the sultan, officials and royal servants wore yellowcolored traditional costumes (Fadillah 2016).

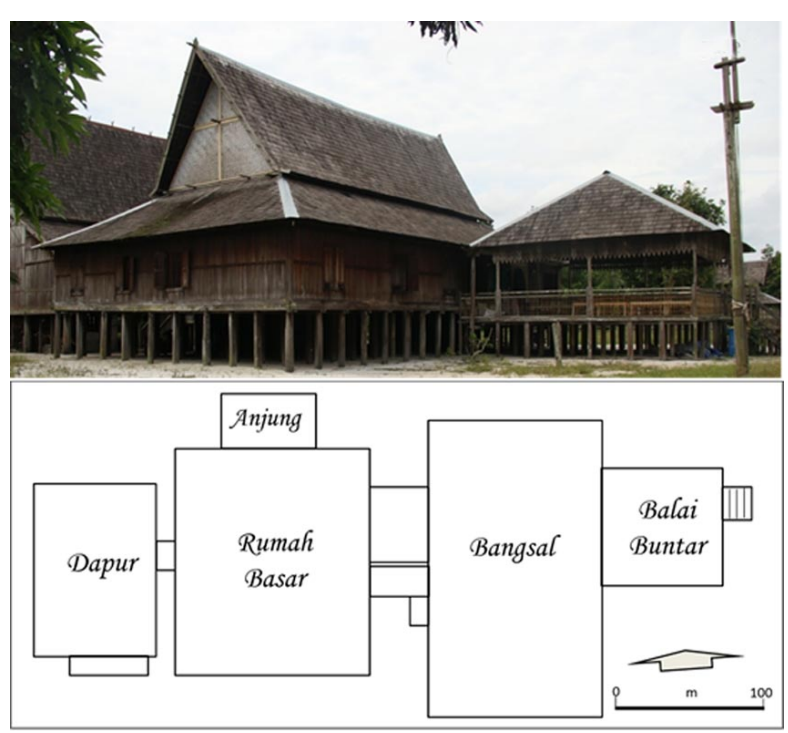

Source: BPCB Kaltim 2019

Figure 11 The South Side of Astana Alnursari, was Restored for the First Time in 1980. The Plan Shows the Division of Space of the Interior

\section{The Shift of the Capital City: An Economic Perspective}

From an economic point of view, the Kotawaringin region is an area that has abundant natural resources. In this area, there are important places that have been exploited, such as Garigadu, Lake Gatal, Lake Asam, Lake Masoraian, Nangabulik, Kudangan, Balai Riam, and Pangkut. Such places provide export products such as rattan, tengkawang (Borneo: tallow nut), resin, gum, agarwood and others. Forest plants have been arranged by the prince or on behalf of the prince. In addition to forest products, the principality also has areas rich in mineral products, such as gold and iron ore, especially in the upper reaches of the rivers. During the reign of Prince
Ratu Imanuddin, gold mines were opened by giving concessions to Chinese workers.

Based on these natural resources, it is clear that the principality of Kotawaringin did not depend only on upeti (tributes) given by the interior and urban population, but also relied on the role of the king in managing trade, hence, the country had an economic foundation. Table 1 shows the development of the prince's income. Initially, he relied more on upeti from the interior (Dayak regional head) or serah, as a compulsory gift of agricultural products from the heads of the Malay community in the region. By the first half of the $19^{\text {th }}$ century, the source of royal income came from profit-sharing of gold, trading in forest products, and most importantly taxing of export and import commodities. As noted by Von Gaffron based on Dutch controleur reports, the official income of principality was more varied. The total income reached 24,680 florins ( $f$ or fl.; Dutch guilder) in 1844 (Pijnappel Gzn 1860).

Table 1 Kotawaringin Official Income in 1844

\begin{tabular}{|c|c|c|}
\hline No & Income sources & Total \\
\hline 1. & $\begin{array}{l}\text { Rice tribute (upeti) from the interior of } \\
\text { Dayak community }\end{array}$ & $f$ 14.940,- \\
\hline 2. & $\begin{array}{l}\text { Asil given by the leaders of the } \\
\text { Moslem community }\end{array}$ & $f \quad 2.840,-$ \\
\hline 3. & $10 \%$ of gold production & $f \quad 2.700$ \\
\hline 4. & Serah from commercial transactions & $f \quad 3.200,-$ \\
\hline \multirow[t]{2}{*}{5.} & $20 \%$ export and import tax & $f \quad 1.000,-$ \\
\hline & Total & $f$ 24.680,- \\
\hline
\end{tabular}

As for the taxing imported goods (see table 2), it will be interesting to present here goods that were supplied for Kotawaringin in the first half of the $19^{\text {th }}$ century. According to the Von Gafron list, as shown in table 2, there are at least seventeen merchandise items, and three of which had the highest value, i.e. European textiles, Chinese porcelain and salt. Meanwhile, Kowaringin's exports since the $17^{\text {th }}$ century consisted of forest products and rice, while imported goods were textile and metal equipment. 
Table 2 Kotawaringin Imported Products in 1844

\begin{tabular}{|c|c|c|c|}
\hline No & Type of goods & Units & $\begin{array}{l}\text { Value in } \\
\text { florijn }\end{array}$ \\
\hline 1. & $\begin{array}{l}\text { Dutch and } \\
\text { English textiles }\end{array}$ & -- & $f$ 18.000,- \\
\hline 2. & $\begin{array}{l}\text { Chinese } \\
\text { porcelain }\end{array}$ & -- & $\begin{array}{ll}f & 6.000,-\end{array}$ \\
\hline 3. & Salt & 20 coyangh & $f \quad 4.400,-$ \\
\hline 4. & Copper goods & 20 picol & $f 3.600,-$ \\
\hline 5. & Rice & 30 coyangh & $f \quad 3.400,-$ \\
\hline 6. & Tobacco & $\begin{array}{l}120 \\
\text { kranjang }\end{array}$ & $f \quad 2.880,-$ \\
\hline 7. & $\begin{array}{l}\text { Household } \\
\text { appliances }\end{array}$ & 100 pièces & $f \quad 2.400,-$ \\
\hline 8. & Opium & 20 bollen & $f \quad 1.500,-$ \\
\hline 9. & Gambier & 80 picol & $f \quad 1.200,-$ \\
\hline 10. & Sugar cane & 60 picol & 900,- \\
\hline 11. & $\begin{array}{l}\text { Oeuf salé } \\
\text { salted eggs }\end{array}$ & 3000 pièces & $500,-$ \\
\hline 12. & Foreign salt & 30 coyangh & $480,-$ \\
\hline 13. & Gunpowder & 400 [?] & $300,-$ \\
\hline 14. & Coconut & 4000 pièces & 280 ,- \\
\hline 15. & Cooking oil & 400 sacs & $200,-$ \\
\hline 16. & Sesame, & 12 picol & $144,-$ \\
\hline 17. & Coffee & 3 picol & $90,-$ \\
\hline & \multicolumn{2}{|c|}{ Total in florin } & f 48.874,- \\
\hline
\end{tabular}

Source: Pijnappel Gzn 1860

Table 2 shows an interesting fact that rice must be imported, whereas according to numerous records from the Dagh Register of VOC, prior to the first half of the $19^{\text {th }}$ century, Kotawaringin was one of the regions that exported rice to Batavia (Fadillah 1996. 317=319: DR 1646-1664). A new hypothesis must be put forward, perhaps at the beginning of the $19^{\text {th }}$ century, the principality was more focused on the economy in trade and services, so that agricultural production of rice was ignored. This case can be compared to the occurrence of a 'pepper boom' in the Sultanate of Banten in the $17^{\text {th }}$ century which required local governments to import rice from other regions of Java to meet the food needs of the population (Guillot 1995). But this hypothesis may have to be reviewed because there is a suggestion that rice production can be constant while population increases, so rice exports will not be an option.

In general, the presence of exported and imported goods can be used as an indicator of increasing economic transactions and also domestic purchasing power. This trading activity is of course the impact of the construction of a new capital city with various port facilities and its management. Hence, it could be stated that the relocation of the capital city of Kotawaringin must be interpreted as an implementation of an important policy of the local government. Therefore it can be inferred that the placement of the first capital city in Kotawaringin Lama did not provide many benefits in the development of the regional political economy. Thus, meaning that the first capital city was not ideal compared to other citystates established on the coast of Kalimantan, such as Pontianak, Sukadana, Matan and Banjarmasin, which are located around large river estuaries providing access to extensive traffic.

Based on such a perspective, the Kotawaringin Lama infrastructure also made it impossible for the country to develop further trade. The first obstacle was that the political center was further upstream, while the waterway did not offer the opportunity to achieve it. The second, gold ore as a mainstay commodity which was exploited around Asam and Masoraian zones, and the horseshoe lake around Kotawaringin Lama, was not enough to meet market needs. In this condition, it is not possible for the principality of Kotawaringin to compete with other politicaleconomic centers. For this reason, Prince Ratu Imanuddin decided to move the capital closer to the river mouth. Prince Ratu Imanuddin's good relations with the Batavian government enabled him to execute such an idea (Fadillah 1996: Index: Ms. Contract-1824, Perkara 1-3).

Politically, the recognition of this country to the Dutch government could guarantee its existence, as was the case with other sultanates in Kalimantan. By placing under the protection of the Batavian Government, it was possible to resolve border conflicts with Matan, a neighboring country in the west, and defend from the threats of pirates in the southern waters of Kalimantan (cf. Lombard 1979). So with the politics of 'shelter for life', instead of 'oppose but die' as happened in the context of the Sultanate of Banjarmasin, such principality was able to integrate itself into the Dutch political-economic system. Here, Batavia played an important role, both as a political center and a port that especially stored forest and mining products of Kotawaringin. In 1809, Prince Imanuddin built Keraton Kuning in Pangkalan Bun, 
and in 1811 the place was chosen as the royal capital and inaugurated as Bandar Sukabumi. Prince Ratu Imanuddin stated in his letter (quote):

"Termaktub di dalam negeri Sukabumi, Kotawaringin Baru" (Declared in Sukabumi city, Kotawaringin Baru).

In the other royal archives, Pangkalan Bun was sometimes called Bandar Sukabumi, meaning city or port of Sukabumi. Based on the sultanate's archives it is known that Prince Imanuddin stated in writing (Sofianto and Pinem 2015; quote):

"Kudirikan Negeri Sukabumi Kutaringin Baru Pongkalan Bu'un untuk anak-anakku, cucucucuku, katurunanku dan orang-orang yang mau berdiam di negeriku dalam pengkuan Kesultanan Kutaringin". (I established Sukabumi, Kutaringin Baru, Pongkalan Bu'un for my children, my grandchildren, my descendants and people who wanted to stay in my country under the protection of the Kutaringin Sultanate).

The opening of Bandar Sukabumi was marked by the erection of 'Pole of Sangga Buana' (a type of earth buffer) on Friday 9 Jumadil Awal 1221 Hijrat or 25 July 1806 CE) The pillar still stands in the alun-alun square today, in the front yard of Keraton Kuning on Bukit Indra Kencana (Sofianto and Pinem 2015). Located on the banks of Sungai Arut about $40 \mathrm{~km}$ from the Kotawaringin bay, this site allows city residents to develop along the river banks. Bandar Sukabumi has sufficient prerequisites to function as a capital city that protects and facilitates economic and trade centers around it. As a result of the prince's strategic implementation, in 1826, Kumai was officially opened as the main port of Kotawaringin. Kumai's position as an estuary port soon has a positive contribution for Pangkalan Bun, which is apparently still located far from the estuary. This first port had since benefited the capital's economic interests. In 1831, the port of Sukamara, which official name was Mulyakerta, became the second port located on Sungai Jelai, on the border of Kotawaringin and the country of Matan (Figure 12).

Unfortunately, there are no sources that may answer the issue concerning the moving of the capital in detail. But let's look at what happened in the sultanate of Banjarmasin or Banten, the movement of the capital from Nagara or Martapura to Banjarmasin (Ras 1990), and in the case of Java, from Banten Girang to Banten Lama as a famous estuary city around the early sixteenth century (Guillot et. al. 1994). The shift of the capital to the river mouth had been preceded by political change, i.e. the fall of the Hindu ruling regime and the growth of Islamic political power on the coast. Nevertheless, the logical reason was economic, because since then, these sultanates have achieved extraordinary progress as a citystate with its cosmopolitan port.

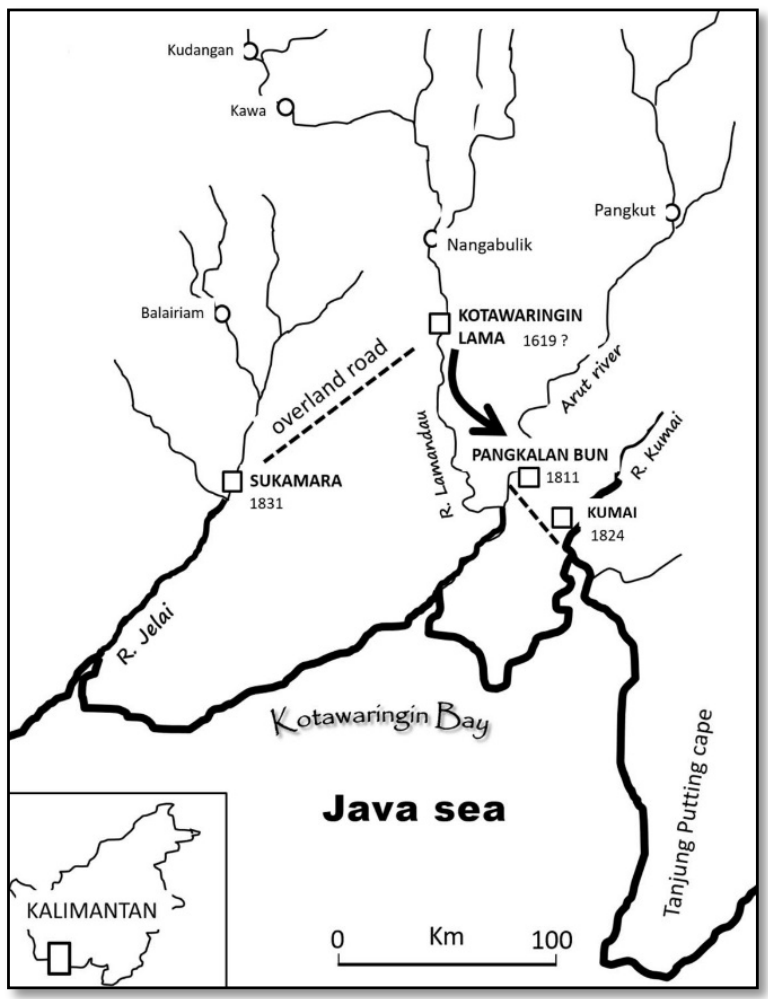

Source: Fadillah 1996; 177, Carte II.7; Sofianto and Pinem 2015

Figure 12 The Territory of Kotawaringin in the Beginning of the $19^{\text {th }}$ Century

Comparing the Kotawaringin case with the port cities, as well as with other ports in the archipelago, it seems that the main motivation for developing estuary power is to encourage maritime trade which is well suited to the economic basis of the coastal city-state. In the case of Kotawaringin, the shift of the capital city can be considered as strategic anticipation from the local government, which is highly likely to be considered by external changes. The fact that Prince Ratu Imanuddin remained on his throne in a rapidly changing political situation, there is no doubt, because of Dutch intervention that guarantees his status.

Our critical point must be directed to the fact that trading activities were concentrated in the 
estuary of Sungai Arut. That way the existence of the royal-city supports the country's economy. When the capital was still in Kotawaringin Lama, control over the traffic of goods and people was only effective in Sungai Lamandau, and it was almost impossible for the king to control trade originating from the interior of Arut. Such was due to merchandises which could reach other places without passing through the capital or its ports. After Pangkalan Bun became the capital, Kotawaringin's authority could control two rivers at once, Sungai Lamandau and Arut. This way, Prince Ratu Imanuddin's decision to move the capital was a strategic step in supporting Kotawaringin's political economy.

Further, for the same reason, the prince had good control over other rivers located in the Kotawaringin region, such as Sungai Kumai that runs in the east, and Sungai Jelai in the west. Hence, the ports must be built on both rivers. Kumai's river mouth was well known as a pirate's nest concentrated in Sei Sekonyer, around the Tanjung Puting swamp zone, while Sukamara has always been in border disputes with the Matan principality, which is now centered in the modern city of Ketapang. However, the Batavian government was able to fulfil Prince Ratu Imanuddin's wishes to build these two ports.

The characteristic of Bandar Sukabumi thus indicates that the Kotawaringin coast in southwestern Kalimantan has also become part of the Southeast Asian trade chain, which was indicated by a 'booming market' on the maritime silk route (Reid 2011). However, with regard to Kotawaringin, it appears to be one of the geographic points that could develop in the later episodes of the golden era of trade in Indonesian waters.

\section{CONCLUSION}

Shifting the capital city is always seen as an important event in the geography of human history because it always brings many changes, especially in terms of demography and urbanization. The similarity in the structure of urban space in the Kotawaringin case allows concluding that royal capital is a centralized model, which is 'the center that must be emulated'. With this conception, the design of satellite cities must be identical to its center in the royal city. Hence, it is interesting to see the agglomeration of river city from two aspects, i.e. symbolic and pragmatic.

Therefore, it is relevant to describe the relationship between the symbolization of the power of the inherited Malay country and the introduction of the modern economic system. Archaeological and historical facts have confirmed the two hypotheses. The first is that local government policies will be effective if they are supported by two factors, which are the political power of the central government (Batavia) and the symbolic power that comes from the local culture. This applies with Dutch political guarantees by making Kotawaringin as zelf-bestuur (autonomous region) as well as a representative of the central government in carrying out colonial economic policies. The symbolic power was in the form of elaboration of Malay-Islamic cultural sources with the exemplary center concept of strengthening the legitimacy of power over all regions in royal control. The second hypothesis is that the role of local government in the market economy will be optimal if it can improve the function of the capital city as a political as well as economic center. This hypothesis is explained by the policy of shifting the capital from the upstream reaches to downstream, construction of port and market facilities, public services in support of urbanization, trade activities, taxation, and security and convenience of multiethnic urban residents.

Thus, if accepted, both hypotheses can be developed for further researches on two important subjects. First, then the symbol of royal power is still needed as the legitimacy of its existence in the inheritance territory. Second, that in dealing with new social and political situations, symbolic power is only effective for regulating internal affairs. Further, economic reasons must be accepted as a necessity to maintain the continuity of the country itself.

On the basis of these hypotheses, the spatial planning of river cities in Kotawaringin can be explained with two perspectives, culture and economy, at one geographical pole as reflected in the urban planning policies implemented at strategic points. If Bandar Sukabumi can be recognized as an 'exemplary center', then there must be an imaginary blueprint to apply to other cities under the prince's control, which were Kumai and Sukamara districts, with their respective claimed territories. Historical evidences of the 
cities on the riverbank leads to the substantiation of the hypotheses.

By looking at the condition of archeological and historical sites in Kotawaringin since the $17^{\text {th }}$ century and more focused in the 19th century, it appears that the philosophical and pragmatic aspects of river cities can be identified in their relevance to the reconstruction of the urban history of the Malay world in Kalimantan. In Kotawaringin,
Prince Ratu Imanuddin's works had answered the research questions. As the founder of Bandar Sukabumi or the city of Pangkalan Bun, he was a historical actor, who has manifested a desire to care for variant Malay cultures but acted proactively to bring his country into the competition to begin the colonial era in southwestern Kalimantan.

\section{REFERENCE}

Atmojo, B. 2013. "Makam-makam dan candi di Negeri Baru dalam perkembangan Sejarah Budaya di Kabupaten Ketapang." Naditira Widya 7 (2): 106-116.

Behrend, T. 1989. "Kraton and Cosmos in Traditional Java." Archipel 37: 137-185.

BPCB Kaltim. 2019. "Laporan Kegiatan Studi Teknis Astana Alnursari, Kecamatan Kotawaringin Lama, Kabupaten Kotawaringin Barat, Provinsi Kalimantan Tengah." Laporan Kegiatan Studi. Kalimantan Timur: Samarinda: Balai Pelestarian Cagar Budaya Kalimantan Timur

Cense, A. A. 1928. De Kroniek van Bandjarmasin, Santpoort: C.A. Mees.

Chambert-Loir, H. 1989. "Etat, cité, commerce: le cas de Bima." Archipel 37: 83-105.

Dijk, L. C. Van. 1962. Neerland's: vorgeste betrekkingen met Borneo, Den soloArchipel, Cambodja, Siam En Cochin-China. Amsterdam: J.H. Scheltema.

Ditlinbinjarah. 1980. Laporan Studi Kelayakan dan Pemugaran Keraton Kotawaringin, Pangkalan Bun, Jakarta: Departemen Pendidikan dan Kebudayaan.

Ditlinbinjarah. 1984. Laporan Pemugaran Mesjid Kiai Gede, Kotawaringin Lama. Jakarta: Departemen Pendidikan dan Kebudayaan.

Encyclopaedie van Nederlandsch-Indie (Eerste dee).1896. Indonesia. s-Gravenhage: Martinus Nijhoff.

Fadillah, M. A; Montana, Suwedi; Nurhakim, Lukman. 1990. "Laporan Penelitian Arkeologi di Kotawaringin Barat, Kalimantan." Laporan Penelitian Arkeologi. Jakarta: Puslit Arkenas.

Fadillah, M. A. 1996. Kotawaringin (Borneo) au XIX Siecle, Etude Archeo-historique sur l'Etat, les cites et le commerce [Ecole des
Hautes Etudes en Sciences Sociales].

Fadillah, M. A. 1998. Formasi Negeri Melayu di Kalimantan, Dinamika Ruang Budaya Masa Indonesia Islam. Pp.203-255 in T. Djubianton et al. (Ed.), Dinamika Budaya Asia Tenggara - Pasifik dalam Perjaanan Sejarah. IAAI Jawa Barat: Balai Arkeologi Bandung.

Fadillah, M. A. 2016. "Bandar Sukabumi pada abad XIX, Pusat Pemerintahan dan Perdagangan di Kesultanan Kotawaringin." Makalah pada Festival Keraton Nusantara $X$, Pangkalan Bun (belum terbit).

Gais, W. O. 1922. The Early relation of England with Borneo to 1805. Bern: Druck von Hermann \& Sohne (Beyer \& Mann).

Guillot, C. 1995. "La politique vivrière de Sultan Ageng (1651-1682)". Archipel 50 (Histoire d'une region): 83-118.

Guillot C., Nurhakim, L, Wibisono, S. Ch. 1994. Banten avant I'Islam, Etude archéologique de Banten Girang (Java - Indonésie) 932? 1526. Jakarta: EFEO-Puslit Arkenas.

Hindarto, I. 2017. "Tinjauan Kesejarahan Situs Candi Negeri Baru." Kundungga 6: 50-60

Kratz, E. U. 1980. "Silsilah Raja-Raja Sambas as a Source of history." Archipel 20: 255-267.

Kusmartono, V. P. R., \& Suhadi, M. 1997. "Catatan Singkat tentang Candi Laras, Provinsi Kalimantan ." Naditira Widya 02: 75-78.

Logan, J. R. 1848. "Trace of the Origin of Malay Country of Borneo Proper." Journal of the Indian Archipelago and Eastern Asia 02: 513-518.

Lombard, D. 1979. "Regard nouveau sur les 'pirates malais' lère moitié de XIXe siècle." Archipel 18: 231-250.

Lombard, D. 1984. "Guide Archipel IV: Pontianak et son arrièrre-pays." Archipel 28: 77-97.

Mallinckrodt, J. 1925. Een en Ander over de 
Gebruiken aan het Kotawaringinsche Hof. Koloniaal Tiijdscrift, 14e jaargang. Batavia: Bookerij van het Koloniaal Instituut.

Manguin, P.-Y. 2000. "Les cités-États de l'Asie du Sud-Est côtière, De l'ancienneté et de la permanence des formes urbaines." BEFEO 87 (1): 151-182.

Nasir, A. H. 1985. Pengenalan Rumah Tradisional Melayu Semenanjung Malaysia. Kuala Lumpur: Darul Fikir.

Pigeaud, T. G. T. 1963. Java in the 14th Century: A Study in Cultural History. Den Haag: Martinus Nijhoff.

Pijnappel Gzn, J. 1860. "Beschrijving van het Westelijke Gedeelte van de Zuid-en Ooster Afdeeling van Borneo." Bataviaasch Genootschap van Kunsten En Wetenschappen 7: 243-346.

Ras, J. J. 1990. Hikayat Banjar. Kuala Lumpur: Dewan Bahasa dan Pustaka.
Rees, W. A. van. 1865. De Bandjermasinsche Krijgs van 1859-1863. Arnhem: D.A. Thieme.

Reid, A. 2011. Asia Tenggara dalam Kurun Niaga 1450-1680: Jaringan Perdagangan Global Asia Tenggara. Jakarta: Yayasan Pustaka Obor Indonesia.

Sofianto, K., and Pinem, M. 2015. Sejarah Kerajaan Kotawaringin", paper on Seminar Sejarah Kesultanan Nusantara, Jakarta: Puslitbang Pendidkan Agama dan Keagamaan, Dept. Agama RI.

Sudibyo, Y. 1984. Mesjid Kiai Gede, Kotawaringin. Kamandalu 3: 23-24 \& 27.

Sulistyanto, B. 2000. Umur Candi Laras dalam Panggung Sejarah Indonesia Kuno. Berita Penelitian Arkeologi 07: 1410-3443.

Usop et al., M. 1979. Monografi Daerah Kalimantan Tengah. Jakarta: Departemen Pendidikan dan Kebudayaan RI. 